\title{
Dietary Levels of Potassium for Broiler Chickens
}

E Author(s)

Oliveira JE

Albino LFT'

Rostagno HS

Páez $\mathrm{LE}^{2}$

Carvalho $\mathrm{DCO}^{2}$

1 Full Professor, Department of Animal Science, Universidade Federal de Viçosa, Viçosa, M inas Gerais, Brazil.

2 Graduate student in Animal Science, Department of animal Science, Universidade Federal de Viçosa. Viçosa, Minas Gerais, Brazil.

\section{Mail Address}

Luiz Fernando Teixeira Albino Departamento de Zootecnia Universidade Federal de Viçosa 36.570-000. Vicosa, MG, Brazil Phone: 55 (31) 38993310

Fax: $\quad 55$ (31) 38992275

E-mail: lalbino@ufv.br

Keywords

Broiler chickens, ion, mineral, potassium, requirement, weight gain.

\section{ABSTRACT}

Three experiments were conducted to determine the nutritional requirements of potassium $(K)$ for male Ross broiler chickens, from 8 to 21,22 to 42 and 43 to 53 days of age. The following parameters were evaluated: body weight gain (BWG), feed intake (FI) and feed conversion ratio (FCR). In each experiment, a completely randomized experimental design was used, with six treatments ( $K$ levels), and six, eight and eight numbers of replicates, and eight, five and four birds per pen, respectively. The experimental diets were basal diets deficient in $\mathrm{K}$ but supplemented with $\mathrm{K}$ carbonate to result in levels of $0.30,0.44,0.58,0.72,0.86$ and $1.00 \% \mathrm{~K}$. Estimated requirements for BWG were $0.628,0.714$ and $0.798 \% \mathrm{~K}$, for the periods $8-21,22-42$ and $43-53 \mathrm{~d}$, respectively.

\section{INTRODUCTION}

Potassium is the third more abundant element of the animal body (McDowell, 1992) and the main intracellular cation. It participates on the processes that are essential to the body homeostasis, such as the acid-base equilibrium, osmotic pressure regulation, development of membrane potentials of cells (nerve transmission, muscle activity, cardiac function), activation of numerous intracellular enzymes, and glucose and amino acid absorption and transport (Rinehart et al., 1968; Reece, 1996; Leeson \& Summers, 2001). Nevertheless Potassium does not work alone and the correct balance between $\mathrm{Na}, \mathrm{K}$ and $\mathrm{Cl}$ is necessary for best animal performance, bone development, eggshell quality and amino acid use (NRC, 1994).

Mogin (1980; 1981) studied the basic role of cation-anion balance for chickens and pigs and concluded that the electrolyte equilibrium could be described by a formula including the main electrolytes. The abbreviated formula resulted in the so-called electrolytic balance (EB), which is the result of the sum of the positive ions ( $\mathrm{Na}$ and $\mathrm{K}$ ) minus the sum of the negative ions $(\mathrm{Cl})$.

According to M urakami (2000), an EB between 150 and $350 \mathrm{mEq} / \mathrm{kg}$ is recommended in commercial diets for maximum bird performance. Leeson \& Summers (2001) considered $250 \mathrm{mEq} / \mathrm{kg}$ as an appropriate level for adequate poultry development.

Hooge \& Cummings (1995) stated that the NRC (1994) K dietary requirements for growing poultry were considerably lower than the levels typically present in commercial diets. No increases in $\mathrm{K}$ requirements were indicated when environmental temperature, water intake, or stress conditions are increased and neither because. The authors also noted that, due to the lack of published research in refereed journals, many of the $\mathrm{K}$ requirements were estimated and presented in italics.

Studies using broilers from 7 up to $21 \mathrm{~d}$ estimated $0.824 \% \mathrm{~K}$ as the potassium requirement with $0.15-0.17 \% \mathrm{Na}$ in a practical-type diet, 
which indicates approximately a $1: 1 \mathrm{Na}: \mathrm{K}$ ratio as optimal and with EB around $242 \mathrm{mEq} / \mathrm{kg}$ (Hurwitz et al., 1973 cited by Hooge \& Cummings, 1995). Thus, this information suggested that the $K$ requirement for maximum BWG could be higher than the $0.30 \%$ level recommended by NRC (1994). Rostagno et al. (2000) suggested that $0.501,0.471$ and $0.454 \% \mathrm{~K}$ were adequate for EB in the periods from 1 to 21,22 to 42 and 43 to $49 \mathrm{~d}$, respectively.

It is still unclear how $\mathrm{K}$ supplementation improves BW, but it has been shown that diets with high levels of lysine $\mathrm{HCL}$ and arginine $\mathrm{HCL}$ might need $\mathrm{K}$ supplementation as acetate or carbonate to minimize the antagonism between these ions on metabolism (O'Dell \& Savage, 1957, O'Dell et al., 1962; Nesheim et al., 1964; Savage, 1972). K salts were also shown to influence lysine catabolism, resulting on lower lysine:arginine ratio (Scott \& Austic, 1978). The protein synthesis and BWG reduced tissue lysine concentration. A possible explanation could be a reduced arginase activity in the kidneys and lower urease activity in the intestines (microbial source). The arginine catabolism would be then reduced and this amino acid would become more available for protein synthesis (Stutz et al., 1972).

Young (1995), in personal communication to Hooge \& Cummings (1995), stated that K levels in some ingredients were found to be considerably lower than expected compared with standard table values, which would alter $\mathrm{K}$ levels and dietary EB calculated by formulas.

Therefore, it is necessary to evaluate the effects of $\mathrm{K}$ levels on broiler chickens performance in order to establish the requirements to determine a recommendation for maximum BWG and to evaluate the need of diet supplementation.

\section{MATERIALS AND METHODS}

Three experiments were conducted in a metabolism room, each one corresponding to the periods from 8 to 21,22 to 42 and 43 to 53 days of age. In the first experiment, 288 Ross male chicks with initial average weight of $0.148 \mathrm{~kg}$ were reared from 8 to 21 days of age in a completed randomized design with six treatments (K levels) and six replicates, with eight birds per experimental unit. In the second and third experiments, 240 and 192 Ross male broiler chickens with initial average weight of $0.768 \mathrm{~kg}$ and $2.295 \mathrm{~kg}$, respectively, were reared from 22 to 42 and 43 to 53 days of age in a completed randomized design with six treatments ( $\mathrm{K}$ levels) and eight replicates of five and four birds per experimental unit, respectively. In the three experiments, $K$ levels of $0.30,0.44,0.58,0.72$, 0.86 and $1.00 \% \mathrm{~K}$ were used.

The birds were housed in metabolism cages, grouped in batteries that corresponded to the experimental units. The diets for each replicate were kept in individual buckets and feed and water intakes were recorded. Birds were reared under conventional conditions until the initial day of each experiment. Diets were formulated according to the age and the nutritional requirements reported by Rostagno et al. (2000).

In all experiments, treatments consisted of a basal diet formulated to fulfil nutritional requirements for all nutrients except for potassium, according to age, based on levels recommended by Rostagno et al. (2000). It was necessary to replace the washed soybean meal for other ingredients with smaller $\mathrm{K}$ content in order to formulate the basal diet deficient in $\mathrm{K}$. The composition of the basal diets used in each experiment are shown in Table 1. Washed soybean meal, used as protein source, was obtained after three washes of the soybean meal with acid solution adjusted to $\mathrm{pH} 4.6$ with hydrochloric acid $(\mathrm{HCl})$, followed by two washes with distilled water, drying in stove at $55^{\circ} \mathrm{C}$ for 24 hours and grinding. The final product contained $90 \% \mathrm{DM}$, $56 \% \mathrm{CP}$ and $0.70 \% \mathrm{~K}$. This procedure was an adaptation of the technique used in the 50 's and 60 's to produce isolated soybean protein and it results in partial loss of $K$ during the washing steps (Supple $\&$ Combs, 1959; Leach et al., 1959). Then, increasing levels of $\mathrm{K}$ were obtained by replacing washed sand for potassium carbonate $\left(\mathrm{K}_{2} \mathrm{CO}_{3}\right)(56.5 \%$ of $\mathrm{K})$. Laboratory analyses were performed to determine $\mathrm{K}$ levels in the experimental diets, which were compared with calculated values.

The diet from each experimental unit was weighed at the beginning and the end of each experiment, and data were corrected for mortality. The birds were individually weighed at the beginning and the end of each experiment. These data were used to obtain feed intake (FI), body weight gain (BWG) and feed conversion rate (FCR) The maximum and minimum temperatures were daily recorded and the means are shown in Table 2.

The statistical analyses were accomplished by the statistical program SAEG (System for Statistical and Genetic Analyses) (Universidade Federal de Viçosa, 1999), and $K$ requirements were estimated using polynomial regression models. A $5 \%$ probability level was used in all comparisons. 


\begin{tabular}{|c|c|c|c|}
\hline Ingredient & 8 to $21 d$ & \multicolumn{2}{|c|}{22 to $42 \mathrm{~d} 43$ to $53 \mathrm{~d}$} \\
\hline Corn, meal \% & 58.500 & 63.000 & 66.730 \\
\hline WSM $^{1}, \%$ & 13.500 & 14.083 & 11.734 \\
\hline Gluten meal $(60 \%$ CP), \% & 10.950 & 9.972 & 8.054 \\
\hline Starch, \% & 3.974 & 2.792 & 4.000 \\
\hline Meat meal, \% & 5.660 & 1.790 & 2.000 \\
\hline Limestone, \% & 0.188 & 0.016 & 0.652 \\
\hline Dicalcium phosphate, \% & 0.050 & 2.190 & 0.824 \\
\hline Soybean oil, \% & 1.000 & 1.000 & 1.653 \\
\hline DL-M et, \% & 0.171 & 0.145 & 0.123 \\
\hline L-Lys $\mathrm{HCl}, \%$ & 0.632 & 0.567 & 0.527 \\
\hline L-Arg, \% & 0.217 & 0.300 & 0.226 \\
\hline L-Thr, \% & 0.070 & 0.060 & 0.012 \\
\hline L-Trp, \% & 0.066 & 0.042 & 0.048 \\
\hline Choline Chlorine $60 \%$, \% & 0.100 & 0.100 & 0.100 \\
\hline Salt, \% & 0.394 & 0.300 & 0.381 \\
\hline \multicolumn{4}{|l|}{ Vitamin/mineral and } \\
\hline additive mix*, \% & 0.238 & 0.238 & 0.238 \\
\hline Washed sand, \% & 4.290 & 3.405 & 2.698 \\
\hline Total & 100.000 & 100.000 & 100.000 \\
\hline \multicolumn{4}{|c|}{ Calculated nutrient composition } \\
\hline ME (kcal ME/kg) & 3.096 & 3.102 & 3.200 \\
\hline $\mathrm{CP}(\%)$ & 21.605 & 20.000 & 18.000 \\
\hline Lys (\%) & 1.263 & 1.156 & 1.050 \\
\hline Met $(\%)$ & 0.542 & 0.494 & 0.437 \\
\hline Met+cys & 0.897 & 0.825 & 0.742 \\
\hline $\operatorname{Trp}(\%)$ & 0.230 & 0.202 & 0.190 \\
\hline Thr (\%) & 0.798 & 0.747 & 0.634 \\
\hline $\operatorname{Arg}(\%)$ & 1.290 & 1.265 & 1.101 \\
\hline Gly+ser, \% & 2.093 & 1.804 & 1.642 \\
\hline Calcium, \% & 0.960 & 0.874 & 0.800 \\
\hline Total P( \% ) & 0.632 & 0.797 & 0.544 \\
\hline Available P (\%) & 0.450 & 0.609 & 0.365 \\
\hline Potassium (\%) & 0.305 & 0.306 & 0.300 \\
\hline Analyzed potassium, \% & 0.334 & 0.315 & 0.320 \\
\hline Sodium (\%) & 0.222 & 0.192 & 0.192 \\
\hline Chlorine (\%) & 0.305 & 0.277 & 0.278 \\
\hline $\mathrm{EB}(\mathrm{mEg} / \mathrm{kg})^{2}$ & 88.53 & 83.64 & 81.82 \\
\hline
\end{tabular}

* Vitamin, mineral and additive levels provided per ton of feed: vit $A$ $10,000,000 \mathrm{IU}$, vit $D_{3} 2,000,000 \mathrm{IU}$, vit $\mathrm{E} 30,000 \mathrm{IU}$, vit $K_{3} 3,000 \mathrm{mg}$, vit $B_{1} 2,000 \mathrm{mg}$, vit $B_{2} 6,000 \mathrm{mg}$, vit $B_{6} 4,000 \mathrm{mg}$, vit $B_{12} 15,000 \mathrm{mcg}$, nicotinic acid $50,000 \mathrm{mg}$, pantothenic acid $12,000 \mathrm{mg}$, biotin 100 $\mathrm{mg}$, folic acid $1,000 \mathrm{mg}$, selenium $250 \mathrm{mg}$, manganese $160,000 \mathrm{mg}$, Iron 100,000 mg, zinc 100,000 mg, copper 20,000 mg, cobalt 2,000 mg, iodine 2,000 mg, vehicle for $1,000 \mathrm{~g} .1$ - Washed soybean meal: $90 \%$ DM, 56\% CP and $0.70 \%$ K.2 - Electrolytic balance: [Na]+[K] - [Cl].

Table 2 - Maximum and minimum mean temperatures $\left({ }^{\circ} \mathrm{C}\right)$ in each trial.

\begin{tabular}{|cccc} 
Age (days) & Maximum & Minimum & Mean \\
8 to 21 & 25.00 & 17.31 & 21.16 \\
22 to 42 & 27.11 & 21.32 & 24.21 \\
43 to 53 & 27.22 & 19.11 & 23.17 \\
\hline
\end{tabular}

\section{RESULTS AND DISCUSSION}

The results obtained for the performance parameters in each experiment are given in Table 3. A quadratic effect on BWG and on FI was observed in the period from 8 to $21 \mathrm{~d}$. The estimated requirements were $0.628 \%$ of $\mathrm{K}$ for BWG and $0.640 \%$ of $\mathrm{K}$ for Fl (Table 4 ). There was no significant effect of $K$ level on FCR.

\begin{tabular}{|c|c|c|c|}
\hline $\begin{array}{l}\text { Potassium } \\
\text { levels (\%) }\end{array}$ & $\begin{array}{c}\text { Feed } \\
\text { intake }(g)\end{array}$ & $\begin{array}{l}\text { Body weight } \\
\text { gain }(g)\end{array}$ & $\begin{array}{c}\text { Feed conversion } \\
\text { ratio }\end{array}$ \\
\hline \multicolumn{4}{|c|}{8 to $21 \mathrm{~d}$} \\
\hline 0.30 & 883 & 616 & 1.432 \\
\hline 0.44 & 926 & 639 & 1.451 \\
\hline 0.58 & 933 & 646 & 1.445 \\
\hline 0.72 & 932 & 650 & 1.435 \\
\hline 0.86 & 917 & 634 & 1.448 \\
\hline 1.00 & 879 & 604 & 1.457 \\
\hline Mean & 911 & 631 & 1.445 \\
\hline Regression & Q & Q & NS \\
\hline CV (\%) & 3.42 & 4.02 & 3.36 \\
\hline \multicolumn{4}{|c|}{22 to $42 \mathrm{~d}$} \\
\hline 0.30 & 2,622 & 1,467 & 1.791 \\
\hline 0.44 & 2,751 & 1,575 & 1.749 \\
\hline 0.58 & 2,843 & 1,625 & 1.749 \\
\hline 0.72 & 2,861 & 1,626 & 1.802 \\
\hline 0.86 & 2,962 & 1,646 & 1.800 \\
\hline 1.00 & 2,791 & 1,553 & 1.799 \\
\hline Mean & 2,805 & 1,582 & 1.782 \\
\hline Regression & Q & Q & NS \\
\hline CV $(\%)$ & 3.46 & 4.08 & 3.94 \\
\hline \multicolumn{4}{|c|}{43 to $53 d$} \\
\hline 0.30 & 1,293 & 539 & 2.421 \\
\hline 0.44 & 1,316 & 615 & 2.153 \\
\hline 0.58 & 1,402 & 599 & 2.364 \\
\hline 0.72 & 1,457 & 652 & 2.257 \\
\hline 0.86 & 1,385 & 616 & 2.251 \\
\hline 1.00 & 1,439 & 627 & 2.302 \\
\hline Mean & 1,383 & 608 & 2.293 \\
\hline Regression & Q & Q & NS \\
\hline CV (\%) 8.16 & 12.46 & \multicolumn{2}{|c|}{8.36} \\
\hline
\end{tabular}

L - linear effect. Q - quadratic effect. NS - not significant.

\begin{tabular}{|c|c|c|c|}
\hline & $\begin{array}{l}\text { irement EB } 1 \\
(\%)\end{array}$ & Regression & $r^{2}$ \\
\hline $\begin{array}{l}\text { Weight gain } \\
\text { Feed intake }\end{array}$ & $\begin{array}{ll}0,628 & 161 \\
0,640 & 174\end{array}$ & $\begin{array}{l}8 \text { to } 21 \text { d } \\
y=522,164^{*}+406,81^{*} x-323,511^{*} x^{2} \\
y=754,471^{*}+570,886^{*} x-445,821^{*} x^{2}\end{array}$ & $\begin{array}{l}0,99 \\
0,98\end{array}$ \\
\hline $\begin{array}{l}\text { Weight gain } \\
\text { Feed intake }\end{array}$ & $\begin{array}{ll}0,714 & 188 \\
0,767 & 201\end{array}$ & $\begin{array}{l}22 \text { to } 42 \text { d } \\
y=1119,05^{*}+1475,65^{*} x-1033,64^{*} x^{2} \\
y=2131,11^{*}+1993,64^{*} x-1299,43^{*} x^{2}\end{array}$ & $\begin{array}{l}0,96 \\
0,87\end{array}$ \\
\hline $\begin{array}{l}\text { Weight gain } \\
\text { Feed intake }\end{array}$ & $\begin{array}{ll}0,798 & 209 \\
0,924 & 241\end{array}$ & $\begin{array}{l}43 \text { to } 53 \mathbf{d} \\
y=404,724^{*}+577,567^{*} x-361,598^{*} x^{2} \\
y=1111,48^{*}+687,004^{*} x-371,363^{*} x^{2}\end{array}$ & $\begin{array}{l}0,77 \\
0,78\end{array}$ \\
\hline
\end{tabular}

1- $\mathrm{EB}=$ electrolytic balance, $\mathrm{mEq} / \mathrm{kg}$. ${ }^{*}$ significant.

The observed requirement levels were $57 \%$ and $109 \%$ higher than the $\mathrm{K}$ levels of 0.40 and $0.30 \%$ recommended by NRC (1984 and 1994, respectively). One of the possible reasons for such difference is that the levels recommended by NRC (1994) were determined using birds Vantress $x$ White Plymouth Rock (Leach et al., 1959), which have smaller grow th potential than the strain used in the present study, mainly in muscle mass. Another reason could be 
attributed to the protein level of the diets. In the study of Leach et al. (1959), protein levels of 25.8 to $37.9 \%$ CP were used, whereas in the current study the level used in the initial phase was $21.4 \%$ of $C P$, as recommended by Rostagno et al. (2000). Nevertheless, this effect was not expected, since theoretically, $K$ requirements would increase with the excess of nitrogen (Leach et al., 1959; Sullivan, 1963; Chavez et al., 1979; Austic, 1983; Hooge \& Cummings, 1995). The levels of $0.628 \%$ and $0.640 \%$ of $\mathrm{K}$ determined in the present study are similar to the level of $0.501 \%$ recommended by Rostagno et al. (2000), although this level has been suggested for an appropriate EB. In the period from 22 to $42 \mathrm{~d}$, a quadratic effect was also observed for BWG and for $\mathrm{Fl}$ (Table 3 ) and estimated levels were $0.714 \%$ and $0.767 \%$ of $K$, respectively (Table 4 ). These values are higher than those obtained in the first experiment. Such requirement increase indicates that muscle development was still occurring, and more $K$ was necessary because of the relation between $\mathrm{K}$ and protein syntheses. The observed levels were $104 \%$ and $138 \%$ higher than those recommended by NRC for this phase, i.e., 0.35 and $0.30 \%$ of $\mathrm{K}$ (NRC, 1984 and 1994, respectively). Environmental temperature was very close to the threshold of thermal comfort (Table 2 ), which could increase $K$ requirements due to poorer intestinal blood irrigation (Bottje \& Harrison, 1986; Wolfenson et al., 1987). As observed in the first experiment, there was no significant difference for FCR.

In the last period, from 43 to $53 \mathrm{~d}$, quadratic effects were also observed for BWG and for $\mathrm{FI}$ (Table 3 ). The estimated levels were $0.798 \%$ and $0.924 \%$ of $\mathrm{K}$ for BW G and for FI respectively (Table 4). These results confirmed the tendency of increase in the requirements, though less markedly, probably due to the decrease in the growth rate. As in the previous experiments, the requirement was higher $(166 \%)$ than the recommendation of 0.30 for this period (NRC, 1984; 1994). There was no significant difference for FCR in the period.

The requirement of $K$ for maximum BWG was preferentially used to determine nutritional requirements. The behavior of the estimated values for this parameter in this study was in agreement with the curves of body composition for $\mathrm{K}$ observed by Kravis \& Kare (1960). They reported that newly hatched chicks had low $\mathrm{K}$ levels and high $\mathrm{Na}$ levels, which oscillated until $12 \mathrm{~d}$ of age. Afterwards, $\mathrm{K}$ levels were high and $\mathrm{Na}$ levels were low, and showed little variation. The behavior was common to almost all tissues, but occurred mainly in muscles, where the content of $K$ at hatching was $30 \mathrm{mEq} /$ $\mathrm{kg}$, reaching a peak of $110 \mathrm{mEq} / \mathrm{kg}$ at $12 \mathrm{~d}$ of age, and was constant at about $90 \mathrm{mEq} / \mathrm{kg}$ afterwards. These findings supports the hypothesis of decreasing requirements with age increase. Conversely, this was not observed in the present experiments; possibly due to the EB of the diets, the reduced lifespan of the modern broiler or even because the renal regulation system was still in development. In any case, the higher $\mathrm{K}$ requirements for broilers nowadays could be explained by the largest potential of muscle mass accumulation in comparison to the birds used in the previous studies.

The estimated $K$ requirements for largest BWG were used to calculate EB values in the three phases (8 to 21,22 to 42 and 43 to $53 \mathrm{~d}$ ). The calculated EB values were 161, 188 and $209 \mathrm{mEq} / \mathrm{kg}$, respectively, and are above the minimum value $(150 \mathrm{mEq} / \mathrm{kg})$ recommended by most studies (Murakami, 2000). This finding evidences a need for better understanding the involved processes and the individual effect of each electrolyte. As the levels of $\mathrm{Na}$ and $\mathrm{Cl}$ in these experiments were constant and in agreement with the recommendations for each phase (Rostagno et al., 2000), it should be considered that the differences observed in this study probably resulted from the interactions among $\mathrm{Na}$, $\mathrm{Cl}$ and $\mathrm{K}$.

Based on the requirements estimated for each phase, it was possible to establish a prediction equation for $K$ requirements as a function of age, for each $\mathrm{Mcal}$ of $\mathrm{ME}$. The curve and the equation are shown in Figure 1. The equation confirmed the increasing tendency of $\mathrm{K}$ requirement levels with age until birds were 53 days old. The level of $0.72 \% \mathrm{~K}$ showed the best BWG in the three periods. Further studies are needed to confirm if the requirements can be maintained or even decreased after the period of intense muscle development.

The potassium levels assessed in the present study affected bird performance. The nutritional requirements of potassium for maximum BWG of birds in the periods from 8 to 21,22 at 42 and 43 to $53 \mathrm{~d}$ were of $0.628,0.714$ and $0.798 \%$ of $K$, respectively. 
Oliveira JE, Albino LFT, Rostagno HS, Páez LE, Carvalho DCO

\section{Dietary Levels of Potassium for Broiler Chickens}

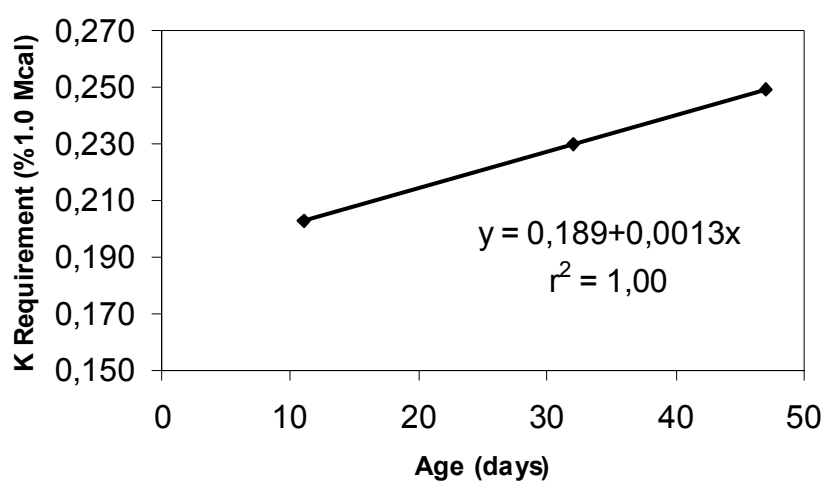

Figure 1 - Estimated potassium requirements for male Ross broilers as a function of age (\% for Mcal ME).

\section{REFERENCES}

Austic RE. Variation in the potassium needs of chickens selected genetically for variation in blood uric acid concentrations. Poultry Science 1983; 62:365-370.

Bottje WG, Harrison PC. The effect of high ambient temperature and hypercapnia on postprandial intestinal hyperemia in domestic cockerels. Poultry Science 1986; 65:1606-1614.

Chavez E, Kratzer FH. Potassium deficiency in the adult male chicken. Poultry Science 1979; 58(3):652-658.

Hooge DM, Cummings KR. Dietary potassium requirements for poultry explored. Feedstuffs 1995; 67:12-16.

Kravis EM, Kare MR. Changes with age in tissue levels of sodium and potassium in the fowl. Poultry Science 1960; 39:13-15.

Leach Jr RM, Dam R, Zeigler RTR, Norris LC. The effect of protein and energy on the potassium requirement of the chick. Journal Nutrition 1959; 68:89-100.

Leeson S, Summers JD. Minerals. In: Nutrition of the chicken. Ghelph, Ca: University Books; 2001. p. 363-377.

McDowell LR. Potassium. In: Minerals in animal and human nutrition. San Diego, Ca: Ed. Academic Press; 1992. p. 98-113.

Mogin P. Role of sodium, potassium and chloride in eggshell quality. In: Proceedings of the Nutrition Conference of Florida; 1980; Gainesville, FL. p.213-223

Mogin P. Recent advances in dietary anion-cation balance: applications in poultry. In: Poultry Proceedings Nutrition Society;1981; 40:285-294.

Murakami AE. Balanço eletrolítico e sua influência sobre 0 desenvolvimento dos ossos de frangos. In: Conferência A pinco de Ciência e Tecnologia A vícolas; 2000; Campinas, SP. Brasil. p. 33-61
Nesheim M C, Leach Jr. RM , Zeigler TR, Serafin JA. Interrelationships between dietary levels of sodium, chlorine and potassium. Journal Nutrition 1964; 84:361-366.

NRC - National Research Council. Nutrient requirements of poultry. $8^{\text {th }}$ ed. Washington, DC: National Academic Press; 1984.

NRC - National Research Council. Nutrient requirements of poultry. $9^{\text {th }}$ ed. Washington, DC: National Academic Press; 1994.

O'Dell BL, Savage JE. Potassium, zinc and distillers dried solubles as supplements to a purified diet. Poultry Science 1957; 36:459-460.

O'Dell BL, Limbaugh CL, Savage JE. Arginine-lysine antagonism and deficiencies of casein for the chick. Federation Proceedings 1962; 21:8.

Reece WO. The kidneys. In: Dukes, physiology of domestic animals. $11^{\text {st }}$ ed. M. J. SWENSON and W. O. REECE, ed. Guanabara Koogan, Rio de Janeiro, Brazil; 1996. p. 521-548

Rinehart KE, Featherston WR, Rogler JC. 1968. Effects of a dietary potassium deficiency on protein synthesis in the young chick. Journal Nutrition 1968; 95:627-632.

Rostagno HS, Albino LFT, Donzele JL, Gomes PC, Ferreira AS, Oliveira DC. Lopes. Abelas brasileiras para aves e suínos. Composição de alimentos e exigências nutricionais. Viçosa: Ed. UFV,2000.

Savage JE. Amino acids and mineral interrelationships. Poultry Science 1972; 51:35-43.

Scott RL, Austic RE. Influence of dietary potassium on lysine metabolism in the chick. Journal Nutrition 1978; 108:137-144.

Stutz MW, Savage JE, O'Dell BL. Cation-anion balance in relation to arginine metabolism in the chick. Journal Nutrition 1972; 102:449458.

Sullivan TW. Studies on the potassium requirement of turkeys to 4 weeks of age. Poultry Science 1963; 42:1072-1075.

Supple WC, Combs GF. Studies of the potassium requirement of turkey poults fed purified diets. Poultry Science 1959; 38:833-835.

Universidade Federal de Viçosa. M anual de utilização do programa SAEG (Sistema para Análises Estatísticas e Genéticas). Viçosa (MG): Ed. UFV; 1999.

Wolfenson D, Sklan D, Graber Y, Kedar O, Bengal I, Hurwitz S. Absorption of protein, fatty acids and minerals in young turkeys under heat and cold stress. British Poultry Science 1987; 28:739742. 